\title{
Introduction
}

\author{
Paulina Aroch Fugellie*
}

\section{Karl Marx and the Geographies of the Present}

https://doi.org/10.1515/culture-2018-0075

Received December 5, 2018; accepted December 28, 2018

\begin{abstract}
The oversaturation of information that characterizes the "digital age" is not only a question of large numbers of competing discourses blurring meaning itself out, but also of a fundamental disassociation between words and their use, between the constative and the performative dimensions of language. Baudrillard has analysed how the mutability of signs in our society has rendered meaning meaningless, through an infinite game of simulacra and simulation that forecloses our understanding of reality rather than making it legible. Meanwhile, Sloterdijk and Žižek have approached the same problematic from a different angle, analysing how actions perform an ideological foreclosure that cannot be observed when analysing signs alone. What discourses say and what they actually do today is often contradictory and this contradiction fulfills an ideological function. This is especially troubling when discourses declare themselves to be counter-hegemonic yet actively participate in the reproduction of the status quo. In this context, it is pertinent to return to the work of Marx to reflect on and engage with his coherent articulation of words and their use, of words and actions, and of the intellectual and the political. The coherence of his discourse and praxis offers tools to think through, if not seek to transform, the alienated semiotic landscape of our times.
\end{abstract}

Keywords: ideology, late capitalism, digital capitalism, semiotics, periphery, praxis

Critical theory, especially the tradition of the Frankfurt School, suggests that the emancipatory or oppressive potential of technological developments in society is not determined by that technology itself, nor by the collective subject which owns the technology. Instead, it is the dialectic between technology and collective subjects, occurring in specific historical contexts, which leads to the realisation of a technology's ambivalent potential in a given historical period. In a similar way, to invoke the name of Karl Marx in 2018 is, within the context of the semiotic, ideological and technological landscape of our times, to call forth a set of ideas, a history and a tradition of ambivalent potential. Marx, understood as a corpus of philosophical and political writings with deep historical significance, holds an emancipatory potential in itself. But like any other signifier, the name of Marx-that is, Marx understood as a signifier of itself-is subject to depoliticisation and appropriation by diverse forces and interests at various historical moments.

After the fall of the Berlin Wall, Marx became quotable in the Western academy and particularly in its U.S. epicentre. His work largely ceased to be a threat. It was rendered acceptable, more readily convertible into cultural capital, made into a value that could be accumulated, stored, used in the making of careers and the distribution of influence. Given this, what does it mean today for us coming from diverse places in universities at the global periphery and core, to celebrate Marx's oeuvre, and the $200^{\text {th }}$ anniversary of his birth, in an open-access online journal? Rather than collate dead hagiographies, in publishing the Call for Papers for this special issue of Open Cultural Studies on "Marx, Semiotics and Political Praxis," I sought to assemble papers committed to the spirit of Marx's work. Essays which understood "Marx" in terms of Foucault's definition of the author: as the articulating principle of a body of texts (Foucault 124-127), and which would remain loyal to Marx by exploring his writing's potential as a tool for transformation in the

*Corresponding author: Paulina Aroch Fugellie, Department of Humanities, Universidad Autónoma Metropolitana, Campus Cuajimalpa, Mexico City, E-mail: p.aroch@gmail.com

ə Open Access. (c) 2018 Paulina Aroch Fugellie published by De Gruyter. (ङ) BY-NC-ND This work is licensed under the Creative Commons Attribution-NonCommercial-NoDerivs 4.0 License. 
contemporary context, a context which includes technological developments, globalized geographies and capital's colonization of the immaterial realm.

The era of digital global capitalism has increased the alienation of our productive lives, interweaving work with the permanent mediation of our sociality through smartphones and social media. Our experience of ourselves, of others, of the products of our labour, of the world at large, unravels into an ever more dislocated pattern of presentation and representation. Experience is stunted at the moment of its emergence, immediately turned into an image, an emulation of itself.

As Jean Baudrillard once argued, in late capitalism the sphere of exchange more than that of production becomes important for the creation of value, and to such a degree that it is exacerbated as a virtual source of value; today, this explains phenomena such as speculative bubbles. Moreover, returning to Baudrillard, this process takes place within semiotics as much as within economics. That is why, in a consumer society, "we see the abolition of the signified and the tautology of the signifier" (124). Baudrillard argues that mass media communications deliver a "certain kind of very imperative message: a message consumption message, a message of ... misrecognition of the world and foregrounding of information as commodity, of glorification of content as sign." He insists that "instead of going out to the world via the mediation of the image ... it is the image which circles back on itself via the world (it is the signifier which designates itself under the cover of the signified)" (124, 123; emphases in text). To Baudrillard's thoughts, we might add Giorgio Agamben's observation that the contemporary dynamics of capital constantly throws words and images out of the sphere of use (107-114), as experience itself, thoughts, images and impulses have become commodified. To put it bluntly: capitalism has colonised the impalpable realms of being and of experience. Contemporary alienation appears at unprecedented levels and in unprecedented forms.

As Marx systematically argued, alienation is correlative to the material conditions of production of a particular society. Marx's Economic and Philosophical Manuscripts of 1844 identifies four types of alienation. First, the worker is alienated from the product of her labour because it is owned and consumed by someone else; the result of her creative labour appears to her as an alien object. Second, the worker lacks control over the process of production, its mode of organisation, the physical and mental conditions and effects resulting from the treatment of men and women as controllable and measurable machines. Third, the worker is alienated from fellow human beings, since social interaction is determined not by that shared and basic humanity, but by human beings rendered into personifications of power, of capital, of exploitability, of knowledge.

Finally, Marx speaks of alienation from our "species-being." What defines our "species-being" is our capacity for conscious labour; labour not only forms the ground of all human relationships but transforms the labourer just as the labourer transforms the world through it. ${ }^{1}$ However, under the capitalist mode of production, labour is destructive rather than creative. It is not a result of personal or collective inclinations. Joy Cox, in a good introductory text to Marx's theory of alienation, clarifies that: "This division of labour meant that workers had to specialise in particular tasks, a series of atomised activities, which realised only one or two aspects of their human powers at the expense of all the others."

Modes of production in the post-Fordist era have increased the degree of fragmentation, and its sheer variety, far beyond what it was two hundred years ago. Enzo Rullani has traced the ways in which these contemporary modes of alienation structure modes of production and modes of circulation, and indeed modes of being in the context of cognitive capitalism. Analyses such as his often centre on the global core, since it is there that much of the service industries and ways of life mediated by new technologies are concentrated. But this pre-empted experience of the self beyond the (fragmented, aestheticised, emptied out) individual is not limited to the global core. The simplistic conception that superstructural forms of alienation and violence tend to affect subjects at the core, with peripheral subjects only affected

1 Gayatri Spivak gives an interesting spin to this idea when she writes that labour-power is "the materialist predication of the subject" ("Speculations on the Question of Value" 109). Her enunciation at once preserves the materialist core of the Marxian subject and transposes that subject to its implication in language.

2 Cox also cites Harry Braverman to propose that: "The unity of thought and action, conception and execution, hand and mind, which capitalism threatened from its beginnings, is now attacked by a systematic dissolution employing all the resources of science and the various engineering disciplines based upon it” (Braverman qtd. in Cox). 
by structural ones, demands dialectical complication. At the periphery, the dislocation of the collective and individual subject often takes place in ways that are, at least, just as violent. Not only is the labourer separated from the product of her work, in a separation diffused ever more effectively over the face of the globe. Beyond even that, as Donald Trump's recent migration policies epitomise, the labourer can be alienated from a right to citizenship, alienated from his children, and these peripheral children can be alienated from their right to family and to political freedom. These are some aspects of the structure that conditions labour in the era of the New International Division of Labour. In another example, what James Ferguson has described as enclaves of extractive transnational capital in Africa break up local communities and alienate individuals from their land, from their means of livelihood, and from their selves as productive beings. In one further example, we might think of unemployment, perhaps the ultimate form of alienation, a pressure that keeps the price of labour low and which is concentrated in the Third World in our ever more integrated global economy.

The alienation of labour across vast swathes of the global periphery is as much an ontological as an economic form of violence. ${ }^{3}$ It impinges on the material lives of peripheral subjects to the point of sickness, starvation and death, but also impinges on their self-relation, their dignity as subjects and their relation to others, often forced (frequently through direct, neo-feudal coercion) into participating in organized crime, which is now often the only viable livelihood in many countries, including parts of Mexico (see Mercille) and Uganda (see Bayart et al.).

I emphasise this point so as to insist on the continued relevance of Marx's reading of the indivisibility between economic conditions and the condition of the subject. In this issue, Claudia Leeb and Stefan Gandler, among others, actualise Marx's point through analyses of the co-constitution of the subject and political economy. Other essays address the foreclosure of the social totality, of the work as unity; they are concerned with the fragmentation of experience, of the self and of language, with alienation from the products of labour and alienation from subjectivity as a product, as in the case of Anu Harju and Ella Lillqvist, Néstor García Canclini and Felipe Victoriano.

Besides the forms of alienation associated to the economic and technological panorama described above, we also witness alienation in terms of institutional politics, with the coming to power of authoritarian rightwing populism in many countries, of which the United States, Brazil, Turkey and Hungary are only some prominent examples. The contradiction between majority class interest and the direction of their vote, that is, the inconsistency between the realm of (political) representation and the realm of represented reality has increased, while the spaces between the content and the performative dimension of the discourses of those representatives have widened too, as Trump's contradictory relation to his own statements epitomizes. Furthermore, the USA president's background in reality TV shows is part of a wider blurring of the lines between political and media forms of representation; we might think of Arnold Schwarzenegger, president Jimmy Morales of Guatemala, or former president Joseph Estrada of the Philippines, where showbiz personae filter into other realms of public life and determine political outcomes. ${ }^{4}$

As Gayatri Spivak has argued, building on Marx's Eighteenth Brumaire, when representation as mimesis or Darstellung (as in the case of showbiz) and representation as a "speaking for" or Vertretung, (as in the case of politics) are conflated, transformation is foreclosed and hegemony reinforced since a rhetorical gesture towards representing the other dissimulates and thus perpetuates the lack of a de facto representation of his or her class interests (“Can the Subaltern Speak?” 70-75). Right-wing populism today-whether directly springing from media culture or not-is a case in which Vertretung behaves as Darstellung. Supposed to represent politically, it in fact only represents aesthetically while pretending to represent politically. It is in

3 Among others, Frantz Fanon's Black Skin, White Masks is a classic testimony of this.

4 The USA political thriller TV series House of Cards employs the rhetorical device of having the main character, acted by Kevin Spacey, address the audience directly by using the second person pronoun and looking at the camera "in the eye" to comment privately on the affairs that are taking place in the scenes at hand at a meta-level of which the other characters are unaware and which has the effect of heightening the sense of realism. Very recently, Spacey, accused in real life of sexual assault and fired from the series, posted a video impersonating his character in House of Cards to rebuke the allegations. By complicating the trope of "realism" in this way, this incident reveals the many and obfuscating layers of reality and fiction that operate in everyday contemporary life and is also an example of how political and media forms of representation are interdependent. 
this conflation between the descriptive/tropological and the performatic/persuasive modes of representation that transformation is stunted. More than enabling emancipatory change, political representation today forecloses the possibility. It does so precisely by emulating and emptying out emancipatory discourse.

As I have suggested, the gap between representation and what it represents has increased in technological and economic contexts, as well as political ones. While new information and communication technologies have further alienated subjects from each other and dislocated them from within, they have also given rise to a speculative economy in which value is sold and bought before actually being produced, straining further the relation between potential value production and its realisation in the market. Given these technological, economic and political contexts of alienation, associated with a separation between discourse and reality, any reconsideration of Marx should engage with his coherent articulation of words and their use, of words and actions, of the intellectual and the political, and his assertion of theory as an intervention in the world. We insist on his eleventh thesis on Feuerbach: "philosophers have only interpreted the world, in various ways; the point is to change it" ("Theses on Feuerbach"). Marx's discourse and praxis offers tools to think through and attempt to transform the alienated semiotic landscape of our times. ${ }^{5}$ An emancipatory recuperation of Marx must displace textual value conceived as originary authority, seeking instead its value in performative disposition and transformative action.

In his essay for this volume, the political philosopher Stefan Gandler addresses precisely that when he analyses Bolivar Echeverría's work to show how the re-elaboration of Marx can become politically operative when responsive to the new context. Revisiting Marx (and Ferdinand de Saussure) by way of Echeverría, Gandler outlines a critical epistemological contestation to intellectual Eurocentrism from the Global South. He argues that Echeverría's analysis of material reproduction-in which he employs semiotics as a tool to explore the relation between individuality and a historically and geographically determined collectivitycan help to understand the productive and consumptive realm of human praxis, without recourse to ethnologising approaches or to biological determinism; an analytical tool that goes far beyond the narrow constrictions of Latin American studies as a field.

Taken together, the contributions by Gandler and Miriam Madureira, also a political philosopher, open up a reflection on the commodification of the semiotic field and on traditional versus specifically neoliberal modes of alienation. Madureira's essay uses the "selfie" to explore what Marx described as the workers' alienation from his own "species-being," from his own humanity. She claims that new forms of self-fetishisation, in which human beings appear to themselves as commodities to be exchanged, emerge in current times of technology-mediated super-exposure. Late-modern subjects, proposes Madureira, define themselves by correlating their potential to their chances of success in the market economy. Making a case for how self-objectification now spreads through all sorts of economic, political, social and intimate relationships, affecting self-interpretation, her essay actualizes Marx in a context quite different to that of Gandler, but driven by the same desire to relate Marx to a new geo-historical configuration of global economic power, correlated to emerging configurations of the self.

The contributions assembled here also open up discussions through their various positions on the appropriate definition of ideology today, the relative importance of material and immaterial labour, and the question of intellectual labour in contemporary society. One set of articles discusses the question of ideology and the need to either return to (Leeb; Harju and Lillqvist) or contest (Hauser) classic Marxist understandings of what ideology is and the way it functions. Claudia Leeb poses the question of why people support leaders who undermine the conditions of their existence. She argues that the money fetish has taken on new importance in the United States, in the form of the neo-liberal capitalist idea that a person's disadvantaged class position is her own fault and that good fortune-and large fortunes-are the result of hard work. The money fetish, she argues, is what made Trump appear to be a successful, intelligent and capable person who could lead people out of their misery and poverty; a mystification of people's consciousness which contributed to his electoral success. She concludes that the money fetish masks domination in production, turning those responsible for the misery of the working class into its apparent saviour. The author's understanding of ideology as false consciousness is made clear in her assertion that

5 For an analysis of Marx’s discourse as praxis, see Victoriano's article in this volume. 
her article is "a contribution to "waking it [the world] from its dream about itself"' (the phrase being a citation from Marx's For A Ruthless Critique of Everything Existing).

In their take on ideology, Anu Harju and Ella Lillqvist set out to examine the processes that allow for the commodification of online participation and exploitative labour relations between capitalist social media organisations and users. They highlight the discursive obscuring of the underlying economic rationale of social media, in which users are sold to advertisers as an unwitting commodity while providing content for the site without compensation. Social media users, they claim, remain complacent about their exploitation thanks to "cognitive illusion" -false consciousness in the Marxist sense-since they have only a partial, and thus misleading, representation of the conditions of their own participation.

In his essay, Michael Hauser offers a quite different take on ideology, focussing on deconstruction. He claims that while the deconstruction of metaphysical concepts once offered a way of contesting authoritarianism, today it has become a legitimation strategy adopting a subversive form. The call for modernist metaphysical ideals such as "unification," voiced by new populist and authoritarian leaders, is paradoxically linked to (rather than undermined by) postmodern rhetorical strategies: consider the "non-linear war" of the Putin administration or Trump's scepticism toward "fake news." Moreover, while authoritarian leaders voice a desire to unify society and create a new identity, fragmented society is actually the sine qua non for them to gain and keep power. Hauser thus suggests that the Marxian concept of the social whole is now the best way to pursue the contestation proposed by poststructuralist deconstruction in its early days, as a tool for a critique of contemporary power.

To recapitulate, we may say that Harju and Lillqvist argue for a return to the definition of ideology as false consciousness in order to understand the changing role of social media today, particularly Facebook, while Leeb considers such a return to be fundamental in making sense of the right-populist turn in institutional politics, particularly in the United States. Michael Hauser, by contrast, calls into question the functionality of such an understanding: in his essay, there is no guarantee of a discourse as always already exempt from complicity with hegemonic ideology, all critical discourses require constant displacement and adaptation. ${ }^{6}$ But all three reclaim the question of ideology as a central concern of the present day. This question of ideology is crucial, not only in view of the latest presidential elections in Poland or in Brazil, for example, nor the transfiguration of the traditional faces of power in virtualised environments, but also because it problematizes a key locus of contemporary ideology, namely the dislocation between words and their use.

Meaning-making has been in a crisis since at least the interwar period when the early Frankfurt School theorists pointed out the development. The process has not stopped: the oversaturation of information characteristic of the "digital age" arguably makes discernment more difficult than ever. It is not simply a question of a vast array of competing discourses blurring out meaning itself, but also of a fundamental disassociation between words and their use, between the constative and the performative dimensions of language. Almost fifty years ago, Baudrillard's analysis showed how the mutability of signs in our society had rendered meaning meaningless, in an infinite game of simulacra and simulation that, instead of making reality legible, forecloses our understanding of it. In the intervening time, the likes of Peter Sloterdijk and Slavoj Žižek have approached the same problematic from a different angle, analysing how ideology today implies inconsistency of action rather than thought, how actions perform an ideological foreclosure that cannot be observed when analysing signs alone. In sum, what discourses say and what they actually do today is often contradictory, and this contradiction fulfils an ideological function. This is especially troubling when discourses declare themselves as counter-hegemonic yet actively participate in the reproduction of the status quo.

Such contradictions are also at stake in Néstor García Canclini's exploration of the mediatised category of citizenship in contemporary society. García Canclini's article, in a lucid translation by Toby Miller, argues that, after television, social networks have come to magnify the conception of citizens as spectators,

6 While building on a very different tradition, Hauser's article advances along the lines of Spivak's “Can the Subaltern Speak?” when she argues that Foucault and Deleuze declare ideology to be démodé and thus produce a schematic opposition between interest and desire. Like Spivak, Hauser is critical of how ideology is conceived only as a being deceived and therefore as only opposite to desire, imagined essentialistically as what one truly wants (Spivak 67-70). 
promising horizontality and social cohesion. Opinions and behaviours are captured by algorithms and subject to globalised forces. The public sphere where citizenship is to be exercised becomes opaque and distant. Citizenship is radically diminishing, although some social movements are reinventing themselves and winning sectorial battles, for human rights, for gender equality, against authoritarianism. Yet the neoliberal approach to technology maintains and deepens greater inequalities. García Canclini thus sets out to explore what alternatives to such dispossession might exist, and the role of the vote when the statesociety relationship has been reprogrammed by technologies and the market. ${ }^{7}$

Put in dialogue with other articles in this issue, García Cancini allows us to reflect on the relationship between what is contemporary, on the one hand, and the sign of the contemporary, on the other. The Argentinean cultural theorist, in exploring the intersection between citizenship and electronic capitalism, investigates a theme that is paradigmatically contemporary, as do a number of other essays: Harju and Lillqvist discuss Facebook, Hauser and Leeb consider the right-populist turns of recent years, while Madureira theorises the selfie. To this, Veronica Redini's article forms an interesting counterpoint: it underlines the persistence and importance of material labour, usually hidden from view, for the continuation of the contemporary economy. As the conversation between these articles suggests, this obfuscation is not innocent, but a structural necessity for the perpetuation of the capitalist mode of production in its present form.

The essay by anthropologist Veronica Redini addresses the continuing importance of industrial production in the era of electronic capitalism and points to the modes of alienation that come with contemporary supply-chain capitalism. She investigates Italian companies that produce in the Republic of Moldova and sell in Western Europe. Through this case study, she argues that today's geographical configuration of production is determined by the economic convenience of low-wage countries for recruiting and managing labour, combined with the possibility of concealing some parts of the production process, for instance, the employment of migrants, or the non-Italian origin of products branded as such. As Redini discusses, delocalisation is a cost-cutting strategy that is obscured by marketing attempts to shift attention from products and production processes towards the client and consumption, a process through which the commodities are increasingly "dematerialised." What is being sold is not a product, but a brand, with associated ethics and aesthetics. These mechanisms obscure the role of labour and the social foundation of commodities, reinforcing commodity fetishism, alienation, and the asymmetrical distribution of value at different ends of the global capitalist network.

In this way, Redini's article brings to the fore the question of the new international division of labour, a central concern in my own text, "Citation as Exchange Value," where I explore it in the context of academic production. Arguing for the need to bring Marx's theory of value into investigations of the (textual, historical and ontological) subject in the globalised world, I use Marx's theory of value, as developed in Capital, to examine the dynamics of accumulation and expropriation at play in academic citation. My focus is on the uneven citation policies that take place across the global core and periphery. I argue that Third World intellectual production is undervalued despite its existence since its validation as cultural capital is retroactively foreclosed by means of hegemonic citation politics. In other words, the problem is not that there is no such production at the periphery. Rather, the problem is that it enters circulation in a way analogous to that in which commodities circulate in the market. By contrast, authors from the global core enter and participate in circuits running parallel to the circulation of capital, rather than commodities. Focussing on the citation strategies of postcolonial theorist Anthony Appiah, I consider what, if any, emancipatory potential is contained within this hegemonic practice of our profession- "our trade" might be the more appropriate term.

In this way, my text approaches that of Stephan Gandler: we share an interest in rereading Marx from the periphery, as well as a mutual concern with intellectual work, and the possibilities and limits of theory as a transformative praxis. But the essay in this issue most centrally concerned with intellectual labour, in fact with Marx's own intellectual labour, is that by Felipe Victoriano, who proposes a reading of Capital going

7 For a relevant review of García Canclini’s contribution see Markin, "Under the Impact of Technology, Digital Capitalism Recasts the Relationships between Citizens, Media and the State.” 
against the grain of what he terms the "analytical devotion" to Marx's classic text. Victoriano considers the implication of life and work, of material existence and productive activity as an essential moment of the book's critical project. He argues that, as proposed by Marx in Capital, capitalism constitutes a system of organization of life, inscribing human labour as workforce, that is, as a commodity, a principle too often forgotten when considering Capital itself as a critical work; and here I emphasize "work" since Capital too is a product of labour, which is Victoriano's central point. The Chilean cultural theorist thus sets out to investigate the nature of the critical text as product, its function in a world where all labour is already inscribed in the logic of capital, and the way in which we might read the manufacture of Capital within a wider productive network, a network at once its object of critique and its condition of possibility.

Furthermore, as with Redini, Victoriano's essay does not deal with the sign of the contemporary, not even with the contemporary as explicit content of analysis. But precisely because of that, both manage to shed light on it. While Redini's essay brings to the fore that which both grounds and hides the paradigm of the contemporary, Victoriano's text allows us to focus on our contemporary act of reading Marx, its material conditions of possibility and its ideological implications, questions too often overlooked in our reading practice. ${ }^{8}$ Overall, despite the different historical epochs addressed by the different essays in this issue, it may safely be said that all of them take on, in one way or another, the uses, misuses and possibilities of Marx in the context of cognitive capitalism, even if only as the place from which one writes. The conscious reflection on the author's own place of enunciation, foregrounded in many of the essays (for example, Bal, Victoriano, Aroch), is one more way in which these texts allow for reflection on the chasm between intellectual discourse and political praxis.

Such a chasm is characteristic of late capitalism. Frederic Jameson famously described the postmodern condition as schizophrenic, with the signifier breaking loose from the signified and spinning around itself in an endless spiral (25-27). Similarly, Agamben wrote that in late capitalism signs are separated from the sphere of use and that signs circulate not to transmit a message (which would imply use value), but as pure medium, exposing their mediality as they exhibit their own act of exhibition (114-119). In sum, the contemporary commodification of the semiotic field and the emptying out of signs as spectacles has severed the political, ethical, ideological, intellectual and even existential scope of work, including academic and artistic work, as a political project.

Dutch cultural theorist Mieke Bal addresses this question when bringing Marxist thought to bear on contemporary art. Interrogating the relation between art, activism and critique, her contribution explores works by Doris Salcedo and other contemporary artists, placing them in a dialogue with the theories of Kaja Silverman, Henri Bergson and Karl Marx. Deploying Marx's and Engels's reading of time and critique of teleology, as found in The German Ideology, interpreted in the tradition of Harry Harootunian, Bal investigates the artworks as material works produced and consumed in historically specific contexts. Her analysis emphasises time itself as both a nonlinear, nontransparent dimension and a central axis for meaning-making. The extrapolation of the Marxian understanding of tempo from the analysis of historical pace (and from capitalism's speed in particular) to the rhythms of the artworks allows Bal to rethink the relations between a citable past, its political activation in the present and the still unrealised potentiality of a time outside-yet-inside history. Through this Marxian take on its objects of analysis, Bal's article represents an innovative rethinking of her earlier publications on "preposterous history."

Taken together, the essays by Victoriano and Bal prompt a reflection on labour as a meaning-creating force in people's lives. Work, in other words, can still be a place of realization of human potential, a place for producing meaning and producing ourselves as meaningful, a place of construction of subjectivity but, as the essays by Harju and Lillqvist, García Canclini, Madureira and Redini attest, this horizon is shrinking rapidly under our current conditions of precarious labour and disembodied labour.

In their different ways, the articles gathered here seek to reconfigure some of Marx's key concepts, not

8 A similarly dialectical reading of the underlying symptoms of the contemporary ideological geography is also, as I have discussed, centrally at work in Michael Hauser's contribution.

9 For a Relevant review of Mieke Bal's article see Markin, “Marx’s Thought Remains Relevant for Contemporary Analyses of Artistic Politics, Modernity and Cultural Production.” 
only labour and labour time but also division of labour, alienation, use value, exchange value, commodity fetishism and class, among others. More often than not, these concepts are reconsidered in the light of the semiotic, technological, aesthetic and ideological constellations of the present. In analysing contemporary semiotic and technological configurations, they expose the dense binds of ideology, its media, corporeal, affective, psychological and existential impact. But they also link this to ideology's more general political, economic, sociological and philosophical functions. While reflecting on ideology's current ruses and double-binds, they recuperate Marx as a condition of possibility for thinking about the present. They confront our current political and cultural conjuncture, so overwhelming when experienced day-to-day, affirming it as explicable and historically determined. Many generations before our own have "turned back" to Marx. Here we proudly do the same in order to come to grips with our disquieting present and future. The need for political change has rarely been so great, the thick clouds of ideological smog rarely denser, both inside and outside ourselves as enunciating subjects. Our analysis continues.

\section{Works Cited}

Agamben, Giorgio. “Elogio de la Profanación.” Profanaciones. Translated by Flavia Costa and Edgardo Castro, Adriana Higalgo, 2005, pp. 97-122.

Baudrillard, Jean. “Mass Media Culture." The Consumer Society. Myths and Structures. Sage, 1988. 99-128.

Bayart, Jean-Francois et al. The Criminalization of the State in Africa. International African Institute and J. Currey, 1999.

Cox, Joy. “An Introduction to Marx's Theory of Alienation.” International Socialism, no. 79, 1998, pubs.socialistreviewindex. org.uk/isj79/cox.htm.

Fanon, Frantz. Black Skin, White Masks. Translated by Charles Lam Markmann, Pluto Press, 1986.

Ferguson, James. "Globalizing Africa?: Observations from an Inconvenient Continent." Global Shadows: Africa in the Neoliberal World Order. Duke University Press, 2006, pp. 25-49.

Foucault, Michel. "What is an Author?" Language, Counter-Memory, Practice, edited and translated by Donald F. Bouchard, Cornell University Press, 1977, pp. 113-138.

Harootunian, Harry. Marx After Marx: History and Time in the Expansion of Capitalism. Columbia University Press, 2015.

Jameson, Fredric. Postmodernism or the Cultural Logic of Late Capitalism. Duke University Press, 1991.

Markin, Pablo. "Under the Impact of Technology, Digital Capitalism Recasts the Relationships between Citizens, Media and the State." Open Science, 30 Nov. 2018, https://openscience.com/under-the-impact-of-technology-digital-capitalismrecasts-the-relationships-between-citizens-media-and-the-state/.

--. "Marx's Thought Remains Relevant for Contemporary Analyses of Artistic Politics, Modernity and Cultural Production." Open Culture: A Companion Blog for Open Cultural Studies, 26 Sept. 2018, https://oc.hypotheses.org/1484.

Marx, Karl. Economic and Philosophical Manuscripts of 1844. Translated by Martin Milligan, Dover Publications Inc., 2007.

---. The Eighteenth Brumaire of Louis Bonaparte. Translated by Saul K. Padover and Progress Publishers Moscow, Marx/Engels Internet Archive, 2010, https://www.marxists.org/archive/marx/works/download/pdf/18th-Brumaire.pdf.

---. Theses on Feuerbach. Translated by W. Lough, Marx/Engels Internet Archive, 2005, https://www.marxists.org/archive/ marx/works/1845/theses/theses.htm.

--. "For a Ruthless Critique of Everything Existing." The Marx- Engels Reader, edited by Richard Tucker, W. W. Norton, 1972, pp 12-15.

--.. Capital, vol. 1. Translated by Ben Fowkes, Penguin, 1990.

Marx, Karl and Frederich Engels. The German Ideology. Edited by C. J. Arthur, translation by International Publishers and Lawrence \& Wishart, International Publishers, 2004.

Mercille, Julien. "Violent Narco-Cartels or US Hegemony? The political economy of the 'war on drugs' in Mexico." Third World Quarterly, vol. 32, no. 9, 2011, pp. 1937-1653. Taylor \& Francis Online, www.tandfonline.com/doi/abs/10.1080/0143659 7.2011.619881.

Spivak, Gayatri Chakravorty. "Speculations on the Question of Value.” The Spivak Reader, edited by Donna Landry and Gerald MacLean, Routledge, 1996 pp. 107-140.

--.. “Can the Subaltern Speak?” Colonial Discourse and Post-Colonial Theory. A Reader, edited by Patrick Williams and Laura Chrisman, Columbia University Press, 1994, pp. 66-111.

Sloterdijk, Peter. Critique of Cynical Reason. Translated by Michael Eldred, University of Minnesota Press, 1987.

Rullani, Enzo. “El capitalismo cognitivo: ¿un déjà vu?” Capitalismo cognitivo, propiedad intelectual y creación colectiva, Traficantes de Sueños, 2004, pp. 99-106.

Žižek, Slavoj. The Sublime Object of Ideology. Verso, 1989. 